於ヶル同樣彇態. 第 1 例=於ケル破壤進行， 狀態. 第 4 例=於ケル初期及ビ外鼻缺損 治療シタル狀態．肉腫組織口二於ケ几血管が同 組織ニョリ壓迫七ラレ 或ハ血管中 =腫演細胞 ガ侵入充塞シタル爿態等 夕。

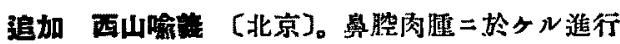

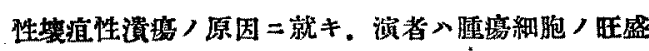
ナル發有. 就中血管丙管殖二因 $ル$ 局所 基ソイタも!ト御見解二對シ、私へ自家經驗ノ組

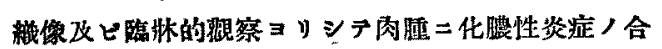
併スル事斗指摘シテ. 既二第 45 回總會，席上發表 敌シマシタノデ迫加メル第デス。

\section{0. ボルトマン術式ニヨリ摘出セル}

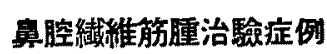

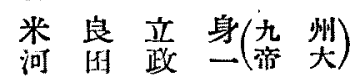

耳鼻咽喉科領域＝於テ固有男腔．副泉腔，鼻

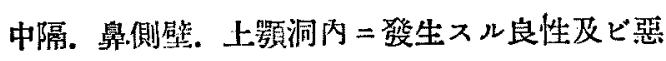
性腫瘍ハ甚ダ多イガ. 固有解腔つ留屋上部ノ天 蓋ヨり發生七ル㵶維筋睡ノ報告八之シイヤウデ アル。最近余等八左側息腔习充セ儿緎維筋腫， 1 例二遭遇シ。ポルトマン術式二依り完全二摘 出シ得タノデ報告シャウト思フ。本症例/34歲

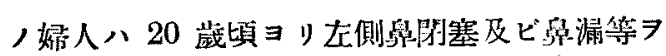
燢エタガ. 3 年前二同侧鼠空二「ポリープ」ア リト云ハレ放邆シタ所。約 1 年南们ヨリ同側二鼻 出血习時々見ル二至ツタ。次イデ左側鼻根部

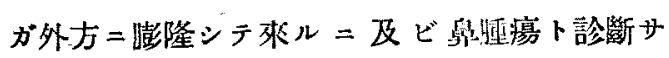
レ. 昭和 17 年 9 月 26 日二賞科へ入院シタ。局 所的二檢スルト左側中蔀位=相當シテ大

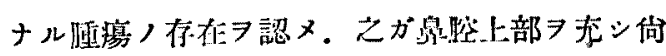

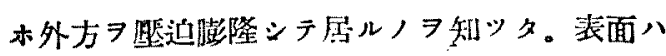

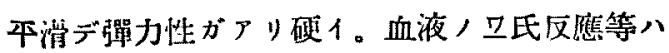
陰性デ. 試驗切片, 組織學的檢查, 結果纎維施
喠ト判明シタ。茲二於テ該腫癔ノ摘出フ企间シ

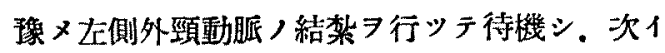
デボルトマン街式＝体り之ガ推出习施行シタ。

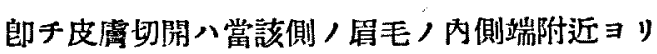

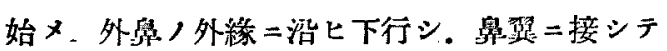
周り身前庭二至ルモノデアル。次イデ骨膜习利 離シ外側デ遊離セシメタル韨屋部フ開キ，鼻骨 卜梨子狀孔 7 露出セシメ. 一侧ノ鼻骨

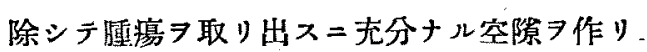
鈍的二周圍ヨリ剥離 7 進 . 逐二其長サ $4.8 \mathrm{~cm}$. 輻 $3.5 \mathrm{~cm}$ 。愿少 $2.2 \mathrm{~cm}$ 。重量 $16.5 \mathrm{~g}$ 八巨大ナ几卵 圆形腫煷ヨ殆ド大シタ出血モナク摘恀シ得タ,

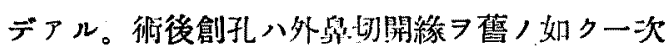
的二䋖合シ 4 日目=拔稀シ經過㥛メテ順調デ。 琎後 36 日目二全治退院シタ。

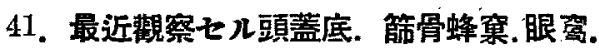

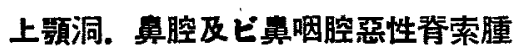

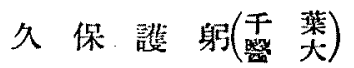

本邦二於示頭蓋底惡性奉索腫，臨林的二診断 セラレ治療セラレタル八現今迄 $=6$ 例ナリシ ガ. 之二今日玄=述ブルモ，ヨ加フレバ7例ナ リ。剖检七ラル、ニ及ンデ確定セルモノ八2例 ナリ。枚二現在迄二本邦二於ケル頭盖底瑟性脊 苶腫，總數ハ9例ナリトス。今年代順ニ之 記スベシ。第1例八大附氏ガ 1923 年東大疗盐 學教室ノ唄藏慓本ヨリ發見セルモノニシテ. 第

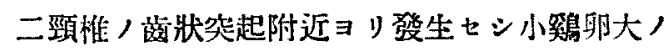
頭盍底瑟性脊索腫ナリ。脊䯣膑二隆起シテ大後 頭孔二及べリ。幽狀等起型=屬ス。本邦二於々 几翢告例，嘴矢トス。第 2 例八 2587 年余力゙観 察セルモノニシテ 隔林的二診断习確定シテ手 術的療法 7 施七几本邦頭蓝底惡性春索喠報告例 ノ最初ノモノトス。4 4 歲ノ男子。兩側蝴揲洞 
ノ前壁及ビ下壁並二其後方頭蓝底剆于奥咽腔， 上壁及ビ後壁二亘り甚ダシク增殖セル巨大ナル モノニシテ。軟口篮习涯迫シ牛球狀二膨隆セル モノナリ。ロ蓝ヨ經テ全剔出 7 行へリ。轉移 7 認メズ。著シキ廣蓄ニ亘りテ頭蓝底骨 7 破壞䄰 貫シテ頭蓝內二達スルニ至ラザル＼cjkstart手遇/際之 ７確定セり．息咽腔型＝屬ス。病理學的診斷八 中村八太郎敉授二依レリ。第 3 例八 1931 年挂 下及ビ传藤兩氏, 報告セルモノナリ。33 歳ノ 女子二發生シ頭蓝底ヨリ右側䇫骨. 上影洞及ビ 鼻空二亘りテ生長シ右側/失明. 右側三叉神經

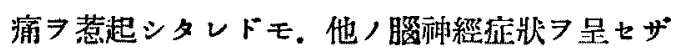
リシ頭蓝底惡性脊索腫ナリ。兩氏二依り斜臺型 トシテ報告セラル。第 4 例八 1932 年山团氏， 報告例ナリ。33 歲/男子。臨牀的二第五. 第 六. 第七. 第儿. 第十一及ビ第十二腦神䌊，麻 瘦厂リ．左側次二右侧／乎身不全麻序. 言語障

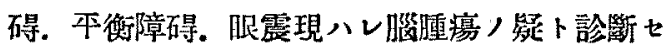
ラレ. 剖檢二依り蝴蝶軟骨聯合ヨリ發生シ. 科 㘆及ビ其附近=蕃殖セル本邦，報告例中最大， 瓷索腫ナル事明カトナレリ。病理學的=良性腫，

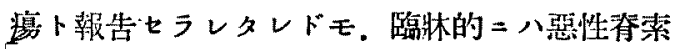

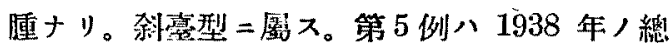
會二於テセルモノニシテ余，第二臨林例ナリ。

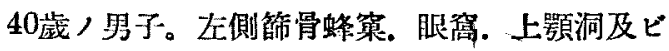

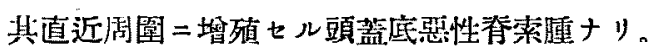
左側頸部二轉移アリ。余，節骨上顎洞型ナリ。 是レ本邦二於テ腺轉移习件へル唯一, 例トス。 第 6 例八1939 年, 總會二報ゼル余，第三臨牀 例ナリ。41歲，女子。左側笠骨蜂策. 眼窩. 上

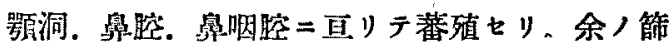

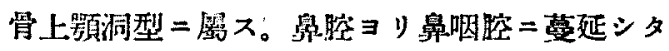
レドモ帠咽腔，頭萳壁ト八關係ナシ。第 7 例八
40 藏,女子二。第 8 例ハ 40 歳ノ女子二來タレ ルモんニシテ. 1941年，總會二報告セル余ノ第 四及ビ第五臨林例ナリ。兩者二於テ頭蓋底惡性

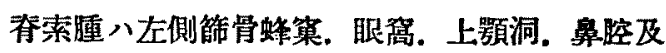
ビ舅咽腔二亘リテ蕃衍セルモノナリ。鼻咽腔= 传入シタレドモ其頭蓋壁卜㗊係ナシ。第 7 例 = 於テ八手術後再發シテ左側乳樣突起二腫瘍，轉 移ヨ生ゼリ。斯カル轉移例八文献二之ヨ見ス。 兩省八余，篩骨上顎洞型=屬ス。第 9 例八49歳 ，男子ニシラ余，第六臨林例 =當レリ．左側笠

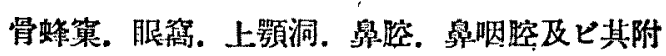
近二增殖䕕延七几頭蓋底惡性春索腫ナリ，鼻咽 腔二侵入シタレドモ其頭篮壁ト關係ナシ。上述 七几余ノ第二. 第三. 第四. 第五及ビ第六例八 敦レモ余，筷骨．上顎型或ハ頭蓋底副舅腔型 (Ethmomaxilkarer Typus oder basilo-para-

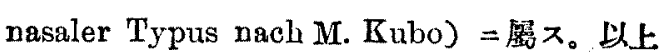
自己經驗=係ル 6 例 7 精查通艦シテ. 其診斷及 ビ治療 =關シ臨林上注意スベキ要項 7 述へタ 1).

\section{2. 上顎㾇ノ臨牀的覞察 特二 路後トノ關係二就テ \\ 中島餐二郎(庭照)}

從來カラ上䫂癌=關スル報告八種々ノ方面二 亘ッテ可成り譜細二施行サしテ居ルガ. 今日尚 木依然トシテ問題，存ズル然八豫後ト，關係= アル。即チ其根治性フ高メルト云フ處二アル。 吾々モ昭和 9 年 10 月カラ 17 年 12 月二亘儿約

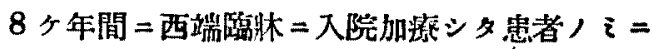

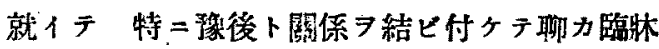
的筧繁 $ア$ 行ッテ見タ。1) 總數 33 侧. 男 24 例 ( 7 例健)，女 9 例 ( 2 例健)。手術例。 26

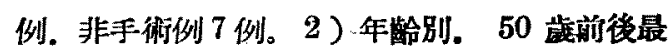

